\title{
Qualitative Study On Drug Users Class IIa Bulukumba Drugs
}

\author{
Misrawati ${ }^{1}$, Asri $^{2}$, Tenriwati $^{3}$ \\ S1 Nursing Study Program, Stikes Panrita Husada Bulukumba, Indonesia ${ }^{1}$ \\ Departemen Community and Family Nursing , Stikes Panrita Husada Bulukumba, Indonesia ${ }^{2}$ \\ Departemen Maternal and Child Healt Nursing , Stikes Panrita Husada Bulukumba ,Indonesia ${ }^{3}$
}

Corresponding Autor : nurasri138@yahoo.co.id *

\begin{abstract}
Illegal drugs are solid or liquid substances, gases that cause physical and psychological changes in the body, almost all drugs affect the central nervous system, drugs act on the brain and can affect anesthesia, view the emergence of side effects and the high persistence to use illegal drugs without being prescribed by a doctor and can cause drug addiction or addiction. Some factors cause drug users, namely environmental factors, family factors and social factors, and 179 drug users in Bulukumba class IIA prisons.The purpose of this study: is to know the factors of the use of illegal drugs in class IIA Bulukumba. The research design used was a qualitative study with a phenomenological approach through in-depth interview techniques. Data was collected in the form of records and results of interviews. Respondents in this study amounted to 6 people using illegal drugs who were selected by purposive sampling. In this study, several theme analysis results were obtained, namely (1) first try (2) the influence of family factors (3) the influence of social factors. Conclusion: Drug users occur as a result of the first try factor, high curiosity, and friend invitations, drug users occur due to family factors, and drug users occur as a result of free sex.
\end{abstract}

Keywords: First Try Factor, Family Factor, Social Factors.

\section{INTRODUCTION}

Illegal drugs are solid or liquid materials, gases that cause physical and psychological changes in the body, almost all drugs affect the central nervous system, these drugs react to the brain and can affect the form of anesthesia, loss of taste sick, excited and hallucinating, with the appearance of hallucinations, it can cause groups of people especially teenagers who have a strong desire to use these drugs even though they do not suffer from any diseases that can threaten their lives and cause danger when using illegal drugs not according to prescription doctors and can cause addiction or drug dependence (addiction) (Rusdi, 2013).

WHO itself provides a definition of illegal drugs is a substance when inserted into the body will affect physical and psychological function (food, water, or oxygen) pharmacological drugs are opioids, over time the existence of drugs is not only as a cure 
but precisely destroy. Initially illegal drugs are still used occasionally in small doses and of course the impact is not very meaningful, but changing times and the mobility of life makes illegal drugs become part of the lifestyle, from what was just a medical set. The prevalence of drug users in the world from 2006 to 2013 has increased. The estimated prevalence of drug abuse in the world is $4.6 \%$ and $4.8 \%$. But then it increased again to 5.2\% in 2011 and remained stable until 2013 (Ramadona \& Agustin, 2014).

The survey results of the National Narcotics Agency (BNN) in cooperation with the UI health research center in 2014 gave birth to the prevalence of drug and drug users in general by $2.18 \%$. Based on the results of the survey, the prevalence rate projection has been calculated, where in 2016 the prevalence of drug and drug users in general was $2.21 \%$ or equivalent to $4,173,633$ people with the details of the addiction or drug category as many as $1,632,636$ people (prevalence of $0.87 \%$ ) the regular try and use category of $1,539,360$ people ( $0.82 \%)$, the category of injecting addicts as many as 70,001 people (prevalence $0.4 \%$ ) and non-injecting addicts as many as 931,636 people (prevalence of 0.49\%) (Ramadona \& Agustin, 2014).

Based on preliminary data collection in Class II A in Bulukumba, drug users, namely the occupancy rate in Class II A in Bulukumba, as many as 179 people overall, drug users and illegal drugs, which here is divided into status, namely male prisoners who use there are 112 drugs and no female convicts. Then the use of illegal drugs is 57 men while women are 10 people. Then the total number of prisoners who use illegal drugs are women and men, as many as 67 people. Researchers are interested in conducting research based on the results of preliminary studies and existing research on "Qualitative studies on drug users in class IIA prisons

\section{MATERIAL AND METHODS}

The research design used in this study is a qualitative study with a phenomenological approach. The reason researchers use qualitative research, because effective qualitative is used to obtain specific information about values, opinions, behavior and social context. In addition, qualitative also provides a complex textual description of how individuals experience something that is a problem in research, especially for sensitive issues, behavior that conflicts with social norms, emotions, relationships between individuals, gender roles, ethnicity and religion. The phenomenological approach is used because the focus of this study is real experience by 
the sample that will be used as respondents. The subject of the study was a description of a qualitative study of illegal drug users in Class II A Bulukumba.

Population is the whole subject and object that are in an area related to the topic of research that meets the characteristics and criteria that have been predetermined and related to the issues raised in the study. (saryono, 2010). The population in this study were 67 drug users in Bulukumba class II A prison. The sampling / information technique in this study uses purposive sampling, which is the technique of selecting participants in a study by determining In this study, researchers used an estimated sample size of less than 10 samples from the drug user population as informants who met the criteria and requirements that has been established by researchers. (Mekar, 2013) states that the sample in qualitative research with phenomenological studies is relatively small, namely less than 10 informants or samples, with consideration of the ability of researchers to explore in depth individual life experiences it is possible to optimize with a relatively small number of samples. So the samples in this study were as many as 6 respondents. first the criteria to be included in the study.

Data is collected through semi-structured interviews that are included in the category of in-depth interviews (in-depth interviews). In-depth interview (in-depth interview) is a way of collecting data using interview guidelines based on interactions between 1 (one) interviewer with 1 (one) respondent as well as the use of open-ended questions. This method is used so that researchers get data that really comes from sources or informants. Data used openly. In conducting interviews, researchers will use interview guidelines that have been made previously. The interview will take \pm 60 minutes to take place at the agreed time and place between the researcher and the informant / respondent. The results of interviews recorded using a voice recorder will be written verbatim in an interview transcript after each interview has been conducted. Having a clear picture of the phenomenon described. Record the data obtained, transcripts data obtained in the form of interviews Finding the form verbatim, Understand the questions of partispan in depth, Having significant recognition, Articulate the meaning of any significant opposition, Group data into various categories and determine the main themes that emerge,Integrate results in an integrated narrative descriptive form, General description in question,Combine data that appears during validation into an in-depth final description. 
RESULTS

The first respondent ( $R / 1$ ) was 31 years old, with a detention period of 1 year 1 month, junior high school level. The second respondent $(R / 2)$ is 33 years old, with a detention period of 1 year, high school education level. The third respondent ( $R / 3$ ) is 45 years old, with a length of detention of 4 years 1 month, a high school education level. The fourth respondent ( $\mathrm{R} / 4$ ) is 33 years old, with a detention period of 8 months, a high school education level. The fifth respondent ( $/ 5)$ is 25 years old, with a detention period of 1 month, junior high school level. The sixth respondent (R / 6) is 34 years old, with a detention period of 2 years 10 months, high school education level. All respondents have similarities in terms of Islam.

Table 1 Distribution of respondent characteristics of drug users in Bulukumba class IIA prisons

\begin{tabular}{lccc}
\hline \multirow{2}{*}{$\begin{array}{l}\text { Code } \\
\text { Respondent }\end{array}$} & & Characteristic & \\
\cline { 2 - 4 } & Age (Year) & Long prisoner & Last Education \\
\hline $\mathrm{R} / 1$ & 31 & 1 year 1 month & Middle \\
\hline $\mathrm{R} / 2$ & 33 & 1 Year & High \\
\hline $\mathrm{R} / 3$ & 45 & 4 year 1 month & High \\
\hline $\mathrm{R} / 4$ & 33 & 8 month & High \\
\hline $\mathrm{R} / 5$ & 25 & 1 month & Middle \\
\hline $\mathrm{R} / 6$ & 34 & 2 year 10 month & High \\
\hline
\end{tabular}

Based on Table 1 Users of illegal drugs who became respondents in this study still maintain the confidentiality of their identity by giving the respondent code " $R$ " taken from the word "respondent" and number 1 as a code sequence for respondents interviewed. R / 1 means the respondent who used illegal drugs was first interviewed, $\mathrm{R}$ / 2 means the respondent who used a second illegal drug, R / 3 means the respondent who used a third drug, R / 4 means the respondent who used a fourth illegal drug , R / 5 means the fifth drug user respondent, R / 6 means the sixth drug user respondent interviewed.

\section{DISCUSSION}

Based on research results obtained through interview techniques obtained information that drug users themselves they use drugs, drugs because of curiosity, curiosity and because of the invitation of friends and a high curiosity to feel something new. Researchers are of the opinion that some respondents use illegal drugs because of the invitation of friends, friends to friends so that they can be affected using these drugs, 
while respondents who say that curiosity is high so they immediately want to consume. Respondents said that the use of illegal drugs is a necessity of life, and is the influence of the environment itself and suggestions.

This is also supported by authoritative research (2013), drug users are usually preceded by someone's bets, persuasions, and pressure or the persuasion of friends or peers. Curiosity or wanting to try is another factor that drives drug users. Haryanto and Haditono (1998) state that victims of drug abuse who reach to the point of dependency will need quite a lot of money to finance their habits, so as a result they often work in vulnerable locations, such as smuggling, robbery, theft, pimping, prostitution and prostitution. gambling.

Researchers are of the opinion that they are not directly using illegal drugs but they are buying and selling illegal drugs with a friend's invitation, there are respondents, trying to buy their own, to the point that there are drug users who have consumed the drug for a long time because it initially just a high curiosity and want to try it yourself. And there are respondents who have already used illegal drugs twice because of the effects of drug addiction, but the respondents who do not directly consume these drugs instead trade because of lack of economic costs. Based on the results of the study found the influence of factors from the family of drug users from the experience of each respondent has a variety of family responses from drug users family concern is very there for drug users, it can be said because many users say always reprimanded by the family or the two old men, but the users are ignorant, such family concerns are admonished, advised, forbidding, and there are still families who come to visit the family in class IIA Bulukumba.

However, in this study it was found that there were also respondents' families who did not know that he was a suspect to date because it might be caused he cared less about the family. But there are respondents saying that every desire must be fulfilled. According to Sudarsono, the family has a very important role in providing education and character building. Since a child is born, cared for in the family, so that the growth and development of his life will not be separated from what is provided by the family. According to Soetjiningsih (2004), which states that the family has a considerable influence on adolescent development because the family is the first social environment to lay the foundations of adolescent personality. 


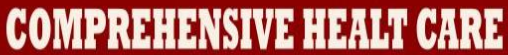

Where the integrity of the family can play an important role in the rise of drug users, many drug users or users of drugs that come from families that are not harmonious, the atmosphere of the house is colored by parents' quarrels that continue to occur, the lack of communication due to busy parents with parents his own work, lack of affection and attention in the family, even parents do not care even if their children go out at night, and have divorced parents, both divorced and divorced. Because of despair and disappointment, users are encouraged to seek a world of escape, namely the use of illegal drugs. Researchers argue that there is an influence from family factors because many users are very ignorant of the family when using illegal drugs because they only think of temporary pleasures that cause side effects from the use of illegal drugs, as for illegal drug users. once cared for his family because of fear, shame as a result of his behavior so that until now no family knew that he was using illegal drugs.

Researchers say there are their hopes related to problems about drug users. Drug users expect that there will be no more or more drug users, because there are already enough drug users or drugs. There is a great motivation expressed by drug users and a large amount of remorse, and has the awareness to improve his life and carry out good worship. But from drug users there is also the influence of promiscuity to the extent that respondents revealed that promiscuity has a very big influence on drug users, respondents to have sex due to promiscuity when using illegal drugs. According to Santrock said that negative relationships can easily lead to bad behavior such as smoking, stealing and using illegal drugs.

The statements of covington (1991) and norwood (1987) lead to the understanding that drug abuse can encourage a person to have sexual relations, where the impulse is not directly caused by the effects of abuse itself, but because sexual conduct is carried out as a result of abuse illegal drugs or sexual behavior is also possible to be able to buy drugs or drugs. Researchers argue that the very large influence of social factors on the use of illegal drugs because many users who fall into the use of illegal drugs due to promiscuity, so there are drug users who often have sex with women who have sex where they will do a very free association, they found these women in the nightlife venue. Association of groups also has the potential to trigger the use of illegal drugs because if there is one user among them then surely all will be affected using or drug dependence. 


\section{CONCLUSIONS}

Based on the results of the research that have been obtained, then some conclusions can be raised as follows: There is a relationship or influence of the factors of drug use such as curiosity, trial and error, invitation from friends, drug dependence and one's own desire to consume drugs, family influence, social influences. Researchers suggest that illegal drugs should not be traded freely, use must be prescribed by a doctor or the correct use. At this time there are many food stalls or places that have been selling drugs freely, however, so that the community is not affected, then provide information or evaluations about the side effects of illegal drugs which can be realized in the form of articles, brochures and the like.

\section{REFERENCES}

Alfiatin, T. (2010). Yogayakarta: Gadjah mada university press.

Dahlan, M. (2010). Besar sampel dan cara pengambilan sampel. Jakarta: Salemba Medika.

Dalami, E., Suliswati, Rochimah, Suryati, k. r., \& Lestari, w. (2014). Asuhan keperawatan klien dengan gangguan jiwa. Jakarta timur: CV.Trans info media.

Dharma, K. K. (2015). Metodologi Penelitian Keperawatan. Jakarta: CV. Trans Info Media. eko, p. (2014). keperawatan jiwa. nuha medika.

Harvina, s. (2015). faktor lingkungan tempat tinggal yang berhubungan dengan berhenti pakai narkoba suntik. jurnal kedokteran dan kesehatan malikussaleh .

Imam, d. (2014). tinjaun hukum pidana terhadap tindak pidana penyalagunaan narkotika (studi kasus dipengadilan negeri surakarta). tinjauan hukum pidana terhadap tindak pidana penyalahgunaan narkotika yang dilakukan oleh anggota TNI, jurnal serambi hukum .

Indrawati, d. (2014). profil keluarga disfungsional pada penyandang masalah sosial di kota semarang. jurnal psikologi undip .

Jannah, R., \& Fajria, r. (2016). Analisis tingkat kecanduan akibat penggunaan narkotika dan obat-obatan terlarang dengan metode fuzzy logic. Teknik informatika fakultas ilmu komputer universitas almuslim .

Lisa, J., \& Sutrisna W, N. (2013). Narkoba psikotropika dan gangguan jiwa tinjauan kesehatan dan hukum. Yogyakarta: Nuha Medika.

Mekar, A. d. (2013). metode kualitatif dalam bidang kesehatan. muha medika. 
Muhammad, a. b., \& Sari, a. f. (2016). Studi kualitatif motivasi pecandu narkoba dalam tahap rehabilitasi untuk berhenti menggunakan narkoba di balai rehabilitasi rsj sambang lihum banjarmasin. Studi kualitatif motivasi pecandu narkoba .

Prabowo, e. (2014). Buku ajar keperawatan jiwa. Yogyakarta: Nuha medika.

Prasanti ditha, K. e. (2017). preservasi kearifan lokal, dalam komunikasi teraupeutik bagi keluarga perkotaan. studi kasus tentang obat keluarga sebagai presevasi kearifan lokal dalam komunikasi terauputik bagi keluarga perkotaan .

Purnomowardani dewanti agnes, K. (2000). penyingkapan diri, perilaku seksual, dan penyalahgunaan narkoba. jurnal psikologi .

Rahardjo, w. (2010). Konsumsi alkohol, obat-obatan terlarang dan perilaku seks beresiko: suatu studi meta-analisis. Jurnal psikologi .

Ramadona, E., \& Agustin, H. (2014). Faktor yang berhubungan dengan penyalahgunaan narkoba di RSJ Prof.HB Saanin. Jurnal kesehatan masyarakat andalas .

Rusdi, D. D. (2013). konsep dan kerangka kerja asuhan keperawatan jiwa. Yogyakarta: Gosyen Publishing.

Saleh, H. D., Rokhmana, D., \& Nafikandini. (2014).

Saryono. (2010). metode penelitian kualitatif dalam bidang kesehatan. muha medika.

Saryono, A. d. (2013). metodologi penelitian kualitatif dalam bidang kesehatan. muha medika.

SRI, W. N. (2015). HUB.. JURNAL.

Suyanto. (2011). Metodologi dan aplikasi penelitian keperawatan. Yogyakarta: Nuha Medika.

Thariqul, M. c. (2014). Terapi indah dan pecandu. jurnal al-murrabi .

Tito, S. S. (2016). analisis penyebab remaja mengkomsumsi narkoba ditinjau dari kesalahan pendidikan keluarga di pontianak. program studi pendidikan sosiologi . 